\title{
Effects of Exogenous Hormones and Glucose on Plasma Levels and Hepatic Metabolism of Amino Acids in the Fetus and in the Newborn Rat
}

\author{
J.R. Girard, I. Guillet, J. Marty, R. Assan and E. B. Marliss
}

Laboratoire de Physiologie du Développement and Hôtel Dieu, Université Pierre et Marie Curie, Paris, France and Department of Medicine, University of Toronto, Toronto, Ontario, Canada

Summary. The present study examines the role of insulin, glucagon and cortisol in the regulation of gluconeogenesis from lactate and amino acids in fetal and newborn rats. Injection of glucagon in the fullterm fetal rat caused a rise in glucose (and insulin) and a fall in blood levels of most individual amino acids, stimulated hepatic accumulation of ${ }^{14} \mathrm{C}$-amino isobutyric acid and ${ }^{14} \mathrm{C}$-cycloleucine and increased the conversion of ${ }^{14} \mathrm{Clactate}$, alanine and serine to glucose in vivo and in vitro (liver slices). Such changes were equivalent to the changes seen in 4 h old newborn rats. When glucagon was administered at birth, little difference was observed between control and treated animals in plasma amino acids and a smaller increment in conversion of ${ }^{14} \mathrm{C}$ substrate to glucose occurred. By contrast, insulin injection at birth caused hypoglycemia, suppression of levels of certain amino acids and inhibition of conversion of ${ }^{14} \mathrm{C}$ substrates into glucose. Glucose injection at birth caused elevated glycemia and plasma insulin and suppression of most amino acid levels and of conversion of ${ }^{14} \mathrm{C}$ substrate into glucose. Cortisol injection at birth caused a marked, generalized hyperaminoacidemia, a stimulation of glucagon secretion and of conversion of ${ }^{14} \mathrm{C}$ substrates into glucose. These observations support the thesis that glucagon plays a major role in the induction of hepatic gluconeogenesis and that insulin acts as an antagonist hormone.

Key words: Plasma amino acids, liver gluconeogenesis, glucose, insulin, glucagon, cortisol, fetus, newborn, rat.

Immediately after birth a dramatic fall in plasma amino acids occurs in the rat $[1,2,3]$, concomitant with a rise in plasma glucagon, a fall in plasma insulin
$[1,4,5,6]$ and a decrease in plasma corticosterone [7]. The fall in plasma amino acids probably results from the competition occurring between utilization of amino acids for growth (protein synthesis) and for gluconeogenesis. Available data on the development of gluconeogenesis from amino acids shows that this pathway has a low activity in the fetus, but develops rapidly after birth $[8,9,10]$. It has also been established that insulin and glucagon play an important role in the appearance of liver phosphoenolpyruvate carboxykinase in the newborn rat [11-14] allowing for the functional development in vivo of hepatic gluconeogenesis $[10,15,16]$.

In the adult animals or man the channelling of amino acids through protein synthesis and gluconeogenesis is regulated largely by insulin, glucagon and corticosteroids $[17,18,19]$. The present study was performed to examine the role of insulin, glucagon and corticosteroids in the control of plasma amino acid levels and in the development of gluconeogenesis in perinatal. rats.

\section{Material and Methods}

\section{Animals}

The rats were an albino Sherman strain bred in the laboratory and fed ad lib on laboratory chow (carbohydrate $47 \%$, protein $20 \%$, fat $8 \%$ ). Fetal age was determined as described previously [1, 10]. Full-term fetuses, on day $21 \frac{1}{2}$ of gestation, were delivered by Caesarean section and maintained unfed in an environment in which temperature was maintained at $37^{\circ} \mathrm{C}$ and relative humidity at $70 \%$. All the fetuses and newborns used in the present study weighted between 5.0 and 5.5 grammes. 


\section{Chemicals}

Insulin (Rapitard ${ }^{\circledR}$ ) and glucagon (Zinc-Glucagon ${ }^{\circledR}$ ) were from Novo Industry, Copenhagen, Denmark. The radioactive compounds used were: 2 -aminoisobutyric acid- ${ }^{14} \mathrm{C}$ (Amersham, Bucks, U.K.), 1-aminocyclopentane carboxylic acid- ${ }^{14} \mathrm{C}$ (New England Nuclear Corp., Boston, Mass., U.S.A.), inulin- ${ }^{3} \mathrm{H}$ (Centre de l'Energie Atomique, Saclay, France), lactate-U- ${ }^{14} \mathrm{C}$ (Amersham, Bucks, U.K.), alanine-U- ${ }^{14} \mathrm{C}$ and serine-U- $-{ }^{14} \mathrm{C}$ (Centre de l'Energie Atomique, Saclay, France), and glutamine- $\mathrm{U}_{-}{ }^{14} \mathrm{C}$ (New England Nuclear Corp., Boston, Mass., U.S.A.). Unlabelled L-alanine, L-serine, L-glutamine, sodium L-lactate and $\alpha$-aminoisobutyric acid were obtained from Sigma Chemical Company (St. Louis, Mo., U.S. A.). Amberlite MB3, 20-50 Mesh was obtained from Fluka A. G. (Switzerland) and Dowex AG 50 WX8, 100-200 Mesh from Bio-Rad (Richmond, California, U.S. A.).

\section{Experimental Procedure}

Under light ether anesthesia, a laparotomy was performed on the pregnant rats on day $21 \frac{1}{2}$ of gestation. The fetal rats were injected subcutaneously through the uterus by means of a microliter syringe (Hamilton Micromeasure, The Hague, the Netherlands) equipped with a 30 gauge needle. Three to five fetuses in one uterine horn were injected with hormones (either $10 \mu \mathrm{g}$ Zinc-glucagon or $400 \mathrm{mU}$ of insulin, in $10 \mu \mathrm{l}$ ) and the fetuses in the other horn received the same volume of fluid used for dissolving the hormones. Since, in the rat insulin [20] and glucagon [21] do not cross the placenta, the solvent-injected fetuses were employed as controls. The rat was allowed to recover from anaesthesia, then samples were obtained $4 \mathrm{~h}$ later. The mothers were anesthetized with $30 \mathrm{mg} / \mathrm{kg}$ pentobarbital intraperitoneally and the fetuses were exteriorized from the uterus, leaving placenta and umbilical cord in situ, thus allowing normal fetal-maternal exchanges during fetal blood sampling. Fetal blood was sampled via an incision across the armpit artery.

Newborn rats delivered by Caesarean section were injected subcutaneously, within two minutes, with $40 \mathrm{mU}$ of insulin, $10 \mu \mathrm{g}$ of glucagon or $0.1 \mathrm{mg}$ of cortisol, in $0.1 \mathrm{ml}$. Controls received the same volume of saline. Cortisol was used in preference to corticosterone since it has the same metabolic effects in the rat fetus, but it was available in the form of a long acting suspension. An additional group, treated in the same fashion, received $10 \mathrm{mg}$ glucose at delivery and $2 \mathrm{~h}$ after birth. They were immediately placed in the water-saturated atmosphere at $37^{\circ} \mathrm{C}$. Blood of newborn rats was sampled $4 \mathrm{~h}$ after the injection of hormones, in unanesthetized animals via an incision across the armpit artery.

\section{Hepatic Accumulation of Amino Acids}

As naturally occurring amino acids are metabolized by the liver, two "non-metabolizable" model amino acids have been employed for transport studies: 2-aminoisobutyric acid (AIB) and 1-aminocyclopentane 1-carboxylic acid (cycloleucine). Fetal rats in situ or newborn rats postpartum (hormone or control injected) received a subcutaneous injection of $0.5 \mu \mathrm{Ci}$ of ${ }^{14} \mathrm{C}$-AIB or ${ }^{14} \mathrm{C}$-cycloleucine and $10 \mu \mathrm{Ci}$ of ${ }^{3} \mathrm{H}$-inulin. Adult rats weighing $300 \mathrm{~g}$ were used for reference and received a subcutaneous injection of $5 \mu \mathrm{Ci}$ of labelled model amino acids, and $10 \mu \mathrm{Ci}$ of ${ }^{3} \mathrm{H}$-inulin.

Blood and liver samples were collected $4 \mathrm{~h}$ after the injections. The blood was centrifuged at $4^{\circ} \mathrm{C}$ and an aliquot of plasma deproteinized in cold $5 \%(\mathrm{w} / \mathrm{v})$ trichloroacetic acid. The liver was excised, blotted on filter paper, weighed, homogenized in a Potter-Elvejhem tissue grinder and deproteinized in $10 \mathrm{vol}-$ umes $(\mathrm{w} / \mathrm{v})$ of $5 \%(\mathrm{w} / \mathrm{v})$ trichloroacetic acid. After centrifugation, an aliquot of the trichloroacetic acid filtrates was added to $10 \mathrm{ml}$ of emulsifier and the radioactivity measured in a liquid scintillation spectrometer (Nuclear Chicago Corp., Des Plaines, Illinois, U.S.A.). The amount of water present in the extracellular space was determined by measuring the inulin space. The total tissue water was measured by determining the difference between the weight of fresh tissue and the same tissue dried to a constant weight at $100^{\circ} \mathrm{C}$. The accumulation of ${ }^{14} \mathrm{C}$-AIB or ${ }^{14} \mathrm{C}$-cycloleucine within the tissue is expressed as a distribution ratio:

Distribution ratio $=\frac{\mathrm{dpm} / \mathrm{ml} \text { intracellular fluid }}{\mathrm{dpm} / \mathrm{ml} \text { plasma }}$

In order to demonstrate whether the effect of glucagon on hepatic uptake of ${ }^{14} \mathrm{C}$-AIB occurred in vitro at fixed concentrations of non radioactive AIB a liver slice incubation technique has been employed. Slices of uniform thickness $(0.4 \mathrm{~mm})$ were obtained with a Mac Ilwain tissue chopper (Micke Laboratory, Surrey, England) from livers of rat fetuses injected in utero with $10 \mu \mathrm{g}$ of glucagon, or the same volume of vehicle, $4 \mathrm{~h}$ previously. About $100 \mathrm{mg}$ of liver slices were incubated for $1 \mathrm{~h}$ in $2 \mathrm{ml}$ of oxygenated KrebsHenseleit medium containing $1 \mathrm{mM}$ AIB and $1 \mu \mathrm{Ci}$ of ${ }^{14} \mathrm{C}$-AIB, maintained at $37^{\circ} \mathrm{C}$, with constant agitation (100 cycles/minute). At the end of the incubation an aliquot of the medium was deproteinized in cold $5 \%$ 
(w/v) trichloroacetic acid and the liver slices were rinsed in cold Krebs-Henseleit medium, blotted on a paper filter, weighed and homogenized in a Potter-Elvejhem tissue grinder and deproteinized in $10 \mathrm{vol}-$ umes $(\mathrm{w} / \mathrm{v})$ of cold $5 \%(\mathrm{w} / \mathrm{v})$ trichloroacetic acid. Calculation of distribution ratio was done as described above.

\section{Conversion of Labelled Lactate and Amino Acids in Vivo}

Four $\mathrm{h}$ after injection of glucagon or vehicle into fetal rats in utero, they were delivered by Caesarean section and kept for $1 / 2, \mathrm{~h}$ at $37^{\circ} \mathrm{C}$ in order to ensure maintenance of body temperature and to allow recovery from the transient hypoxemia accompanying delivery. They were then injected intraperitoneally with labelled precursors $(0.1 \mu \mathrm{Ci}$ per $\mathrm{g}$ of body $\mathrm{wt})$ and blood was sampled 30 minutes later. In other experiments, similarly delivered newborn rats received 40 $\mathrm{mU}$ of insulin, $0.1 \mathrm{mg}$ cortisol, $10 \mu \mathrm{g}$ of glucagon, or saline, subcutaneously, immediately after birth. Four $\mathrm{h}$ later they were injected intraperitoneally with labelled precursors $(0.1 \mu \mathrm{Ci}$ per $\mathrm{g}$ of body wt) and blood was sampled 30 minutes later. Blood samples were deproteinized with barium hydroxide and zinc sulfate and labelled glucose was separated from labelled substrate by mixing the protein-free supernatant with moist Dowex 50 WX8 and Amberlite MB3 and shaking for 30 minutes [22]. This resin treatment was found to remove over $99 \%$ of the lactate ${ }^{14} \mathrm{C}$ and amino acid ${ }^{14} \mathrm{C}$ and is a standard method for removal of other labelled anions and cations. Between 90 and $95 \%$ of the labelled glucose was recovered in the supernatant with this treatment. Incubation of the supernatant with glucose oxidase to convert glucose to gluconic acid and then passing this incubation mixture through a column containing $2.5 \mathrm{ml}$ of Dowex and amberlite showed a retention of more than $93 \%$ of the counts present in the glucose fraction. The method was thus considered to give a close approximation of glucose ${ }^{14} \mathrm{C}$. The percentage of administered radioactivity converted into labelled glucose 30 minutes after injection was calculated on the basis of a glucose space of $60 \%$ body weight in the newborn rats [23]. Appropriate corrections have been included for recovery and quenching.

$\%$ conversion to glucose $=$

$100 \times \frac{\text { Glucose space }(\mathrm{ml}) \times \text { Glucose }{ }^{14} \mathrm{C} \text { in blood }(\mathrm{dpm} / \mathrm{ml})}{\text { administered radioactivity }(\mathrm{dpm})}$

Substrate pool was calculated on the basis of a lactate space assumed to equal the total body water, i.e., 80 $\mathrm{ml} / 100 \mathrm{~g}$ body weight and of an amino acid space to equal the extracellular body water, i. e., $60 \mathrm{ml} / 100 \mathrm{~g}$ body weight in newborn rats [24]. These assumptions have been found correct when they are compared to glucose, lactate and amino-acid pools measured in perchloric extracts of newborn rats frozen in liquid nitrogen (data not shown). The rate of gluconeogenesis from different substrates was calculated, assuming that 2 molecules of substrate gave 1 molecule of glucose, by multiplying the substrate pool by the $\%$ conversion to glucose. Standard error of the means of the product was calculated according to Olcott [25]. Results are given in $\mu \mathrm{mol} / \mathrm{hr} /$ animal, and $\mu \mathrm{mol} / \mathrm{hr} / 100 \mathrm{~g}$ body weight. In newborn rats injected with vehicle or glucagon in utero and studied $30 \mathrm{mi}^{-}$ nutes after birth, lactate, alanine and glutamine were assayed by enzymatic fluorimetric microtechniques in filtrates of blood or plasma as described previously [1].

\section{Hormone Assays}

Plasma insulin and glucagon were determined by radioimmunoassay as previously described [1]. The antiserum employed for the glucagon assay (Unger $30 \mathrm{~K}$ ) is considered to be relatively specific for pancreatic glucagon.

\section{Conversion of Labelled Lactate and Amino Acids by Liver Slices in Vitro}

Liver slices were obtained as described, from glucagon-treated rat fetuses. In this instance the medium contained $10 \mathrm{mM}$ of substrate and $0.5 \mu \mathrm{Ci}$ of the same radioactive substrate, employing the same incubation conditions. At the end of the incubation, an aliquot of the medium was deproteinized with barium hydroxyde and zinc sulfate, and the slices were transferred into $60 \%(\mathrm{w} / \mathrm{v})$ potassium hydroxide for extraction of glycogen $\left(3 \mathrm{~h}\right.$ at $\left.100^{\circ} \mathrm{C}\right)$. The proteinfree filtrate of medium was treated with ion exchange resins as described above to separate glucose ${ }^{14} \mathrm{C}$ from substrate $-{ }^{14} \mathrm{C}$ and an aliquot of supernatant was counted in a scintillation spectrometer (Nuclear Chicago Corp., Des Plaines, Illinois, U.S. A.). The potassium hydroxide extract of liver slices was treated as follows. After precipitation by ethanol and washing, the glycogen was dissolved in water and an aliquot was counted. The rate of conversion of labelled substrate into glucose and glycogen by liver slices was expressed as $\mu$ moles of substrate incorporated into glucose and glycogen per $\mathrm{h}$ per $\mathrm{g}$ of wet liver slices.

\section{Amino Acid Analysis}

The analysis of free amino acids was performed on plasma deproteinized with sulfosalicylic acid as described previously [21] using the automated ion-ex- 
Table 1. Blood glucose and plasma insulin and glucagon in full-term fetal and newborn rats $4 \mathrm{~h}$ after insulin, glucagon, glucose or cortisol administration

\begin{tabular}{|c|c|c|c|c|c|}
\hline & Controls $^{\mathrm{a}}$ & Insulin & Glucagon & Glucose & Cortisol \\
\hline \multicolumn{6}{|l|}{ A. Full-term fetal rats } \\
\hline $\begin{array}{l}\text { Blood glucose } \\
\mathrm{mM}\end{array}$ & $\begin{array}{l}3.6 \pm 0.3 \\
(5)\end{array}$ & $\begin{array}{l}1.6 \pm 0.2^{d} \\
(5)\end{array}$ & $\begin{array}{l}4.1 \pm 0.2^{b} \\
(5)\end{array}$ & - & - \\
\hline $\begin{array}{l}\text { Plasma insulin } \\
\mu \mathrm{U} / \mathrm{ml}\end{array}$ & $\begin{array}{l}228 \pm 16 \\
(7)\end{array}$ & $\begin{array}{l}>800 \\
(5)\end{array}$ & $\begin{array}{l}509 \pm 67^{\mathrm{d}} \\
(8)\end{array}$ & - & - \\
\hline $\begin{array}{l}\text { Plasma glucagon } \\
\mathrm{pg} / \mathrm{ml}\end{array}$ & $\begin{array}{l}311 \pm 26 \\
(5)\end{array}$ & $\begin{array}{l}347 \pm 40 \\
(5)\end{array}$ & $\begin{array}{l}1277 \pm 240 \\
(5)\end{array}$ & - & - \\
\hline $\begin{array}{l}\text { Insulin/glucagon } \\
\text { Molar ratio }\end{array}$ & 17 & $>53$ & 9.2 & - & - \\
\hline \multicolumn{6}{|l|}{ B. Newborn rats } \\
\hline $\begin{array}{l}\text { Blood glucose } \\
\mathrm{mM}\end{array}$ & $\begin{array}{l}3.5 \pm 0.3 \\
(5)\end{array}$ & $\begin{array}{l}0.8 \pm 0.1^{\mathrm{a}} \\
(5)\end{array}$ & $\begin{array}{l}4.7 \pm 0.2^{c} \\
(5)\end{array}$ & $\begin{array}{l}5.8 \pm 0.3^{\mathrm{d}} \\
(5)\end{array}$ & $\begin{array}{l}4.5 \pm 0.4^{\mathrm{c}} \\
(12)\end{array}$ \\
\hline $\begin{array}{l}\text { Plasma insulin } \\
\mu \mathrm{U} / \mathrm{ml}\end{array}$ & $14 \pm 1$ & $\begin{array}{l}80 \pm 19^{c} \\
(5)\end{array}$ & $\begin{array}{l}57 \pm 9^{c} \\
(5)\end{array}$ & $\begin{array}{l}247 \pm 39^{d} \\
(5)\end{array}$ & $\begin{array}{l}35 \pm 2^{\mathrm{d}} \\
(12)\end{array}$ \\
\hline $\begin{array}{l}\text { Plasma glucagon } \\
\mathrm{pg} / \mathrm{ml}\end{array}$ & $\begin{array}{l}340 \pm 30 \\
(5)\end{array}$ & $\begin{array}{l}264 \pm 14 \\
(5)\end{array}$ & $\begin{array}{l}1748+317 \\
(5)\end{array}$ & $\begin{array}{l}418 \pm 48 \\
(5)\end{array}$ & $\begin{array}{l}954 \pm 90^{\mathrm{d}} \\
(12)\end{array}$ \\
\hline Insulin/glucagon & & & & & \\
\hline Molar ratio & 0.96 & 7.05 & 0.87 & 13.8 & 0.86 \\
\hline
\end{tabular}

Means \pm SEM of number of observations shown in parentheses.

a Fetuses were injected with the solvent used for the glucagon and insulin solutions.

b $\mathbf{P}<0.05$

c $P<0.02\}$ when compared to control, Student unpaired $t$ test.

d $P<0.01$

change chromatographic technique on a Beckman $120 \mathrm{C}$ amino acid analyzer (Beckman Instrument Inc., Palo Alto, California, U. S. A.). An accelerated singlecolumn technique enabling separation of basic as well as acidic and neutral amino acids was employed [26]. Since a lithium buffer system was employed, and since sample storage was not inordinately protracted, results for glutamine, glutamate, asparagine and aspartate are presented.

All results are expressed as mean \pm standard error of the mean. Calculation of statistical significance of differences between the groups was performed using the Student unpaired $t$ test.

\section{Results}

\section{Effects of Exogenous Hormones and Glucose on Blood Substrates and Hormones}

Results of exogenous hormone injection into fetal rats are presented in Table $1 \mathrm{~A}$. Insulin produced several changes in samples obtained $4 \mathrm{~h}$ after injection. By comparison with control (solvent-injected) animals, extremely high insulin levels were observed, concomitant with extremely low blood glucose and unchanged plasma glucagon values. Hence, a markedly elevated insulin/glucagon molar ratio was obtained. Glucagon injection, by contrast, caused hyperglycemia, elevated insulin levels, and markedly increased the measured circulating glucagon. Accordingly, the insulin/glucagon ratio was decreased when compared with the controls.

Injection of hormones or glucose into newborn rats produced the results presented in Table 1B. Insulin caused a sustained hypoglycemia, with insulin levels at $4 \mathrm{~h}$ after injection sixfold greater than control. As observed in the fetus, despite the hypoglycemia, glucagon levels were equivalent to controls. Hence the increase in insulin/glucagon molar ratio was the same as the increment in insulin. Glucagon injection again caused changes as seen in the fetus. An increase in blood glucose concentration, as well as a significant increase in insulin levels, accompanied the fivefold higher glucagon levels when compared with control animals. The insulin/glucagon ratio was thus unchanged.

Glucose injection into the newborn at birth and again at $2 \mathrm{~h}$ maintained glycemia at higher levels, and resulted in effective stimulation of insulin secretion. However, plasma glucagon was not decreased, notwithstanding the higher blood glucose levels; hence, the insulin/glucagon ratio observed was equivalent to that seen in the control, full-term fetus. 
Cortisol injection into the newborn at birth resulted in a significant rise of blood glucose, plasma insulin and glucagon levels. The insulin/glucagon achieved was equivalent to that seen in the control or glucagon-injected newborn rats.

\section{Effects of Exogenous Hormones on Plasma Amino Acids in Fetal Rats}

Four $\mathrm{h}$ after injection of $10 \mu \mathrm{g}$ of glucagon into fullterm fetal rats a decrease in plasma level of most of the amino acids was observed, compared with controls (Table 2). Only proline, glutamate, asparagine, methionine, and isoleucine were not significantly modified, whereas the remainder showed declines of up to $50 \%$ of control values.

Four h after injection of $40 \mathrm{mU}$ of insulin in the full-term fetal rats, a fall of plasma amino acids also occurred, but to a lesser extent and affecting fewer amino acids (Table 2). Glutamine, alanine, aspartate, glutamate, the three branched-chain aminoacids (valine, leucine and isoleucine) ornithine, arginine and citrulline decreased. By contrast with glucagon, glutamate and isoleucine showed significant decreases, and taurine increased. From these results it can be proposed that the fall of threonine, serine, phenylalanine, tyrosine, glycine, histidine, lysine and half cystine were relatively specific for glucagon treatment. Glucagon decreased plasma alanine more than insulin, whereas insulin decreased glutamine slightly more than glucagon.

\section{Effects of Exogenous Hormones on Plasma Amino Acids in Newborn Rats (Table 3)}

There is almost total absence of differential response between control and glucagon-injected newborn rats. Levels of taurine were higher in the glucagon-treated, and of tyrosine and arginine were significantly lower. In contrast, the administration of insulin caused significant decline in asparagine, glutamic acid, citrulline, alanine, lysine and arginine with reference to the control group.

The administration of cortisol caused a generalized, marked hyperaminoacidemia, in which only citrulline and tyrosine did not participate. In particular, mean glutamine and alanine levels both exceeded $1000 \mu \mathrm{M}$.

In contrast, the administration of glucose to newborn rats caused suppression of levels of 16 of 21 measurable amino acids to levels even lower than in the control.
Table 2. Plasma amino acids $(\mu \mathrm{M})$ in full-term fetal rats $4 \mathrm{~h}$ after injection with insulin or glucagon

\begin{tabular}{lrcc}
\hline n & Controls $^{\mathrm{a}}$ & Glucagon & \multicolumn{2}{l}{ Insulin } \\
\hline & \multicolumn{1}{c}{$(5)$} & \multicolumn{1}{c}{$(6)$} & \multicolumn{1}{c}{$(5)$} \\
Taurine & $210 \pm 35$ & $172 \pm 46 \mathrm{NS}$ & $289 \pm 20^{\mathrm{b}}$ \\
Aspartic acid & $57 \pm 5$ & $31 \pm 2^{\mathrm{c}}$ & $27 \pm 2^{\mathrm{d}}$ \\
Threonine & $366 \pm 43$ & $199 \pm 22^{\mathrm{d}}$ & $312 \pm 29 \mathrm{NS}$ \\
Serine & $384 \pm 47$ & $181 \pm 23^{\mathrm{d}}$ & $297 \pm 40 \mathrm{NS}$ \\
Asparagine & $131 \pm 28$ & $194 \pm 53 \mathrm{NS}$ & $82 \pm 7 \mathrm{NS}$ \\
Glutamine & $763 \pm 154$ & $470 \pm 80^{\mathrm{b}}$ & $381 \pm 56^{\mathrm{c}}$ \\
Glutamic acid & $188 \pm 28$ & $195 \pm 28 \mathrm{NS}$ & $127 \pm 6^{\mathrm{b}}$ \\
Proline & $295 \pm 63$ & $215 \pm 32 \mathrm{NS}$ & $196 \pm 22 \mathrm{NS}$ \\
Citrulline & $45 \pm 3$ & $36 \pm 5^{\mathrm{b}}$ & $22 \pm 2^{\mathrm{d}}$ \\
Glycine & $330 \pm 26$ & $186 \pm 20^{\mathrm{d}}$ & $308 \pm 58 \mathrm{NS}$ \\
Alanine & $842 \pm 116$ & $338 \pm 47^{\mathrm{d}}$ & $455 \pm 44^{\mathrm{c}}$ \\
Valine & $449 \pm 39$ & $238 \pm 18^{\mathrm{d}}$ & $285 \pm 33^{\mathrm{c}}$ \\
Half cystine & $185 \pm 23$ & $106 \pm 6^{\mathrm{c}}$ & $163 \pm 36 \mathrm{NS}$ \\
Isoleucine & $203 \pm 23$ & $165 \pm 26 \mathrm{NS}$ & $116 \pm 17^{\mathrm{c}}$ \\
Leucine & $272 \pm 22$ & $167 \pm 8^{\mathrm{d}}$ & $173 \pm 7^{\mathrm{d}}$ \\
Tyrosine & $227 \pm 36$ & $121 \pm 15^{\mathrm{c}}$ & $195 \pm 46 \mathrm{NS}$ \\
Phenylalanine & $235 \pm 17$ & $136 \pm 7^{\mathrm{d}}$ & $276 \pm 36 \mathrm{NS}$ \\
Ornithine & $78 \pm 8$ & $37 \pm 6^{\mathrm{d}}$ & $41 \pm 5^{\mathrm{d}}$ \\
Lysine & $972 \pm 80$ & $449 \pm 61^{\mathrm{d}}$ & $958 \pm 192 \mathrm{NS}$ \\
Histidine & $123 \pm 17$ & $36 \pm 1^{\mathrm{d}}$ & $93 \pm 11 \mathrm{NS}$ \\
Arginine & $206 \pm 18$ & $79 \pm 10^{\mathrm{d}}$ & $79 \pm 31^{\mathrm{c}}$ \\
Methionine & $152 \pm 56$ & $110 \pm 35 \mathrm{NS}$ & $143 \pm 42 \mathrm{NS}$ \\
\hline
\end{tabular}

Means \pm SEM of number of observations shown in parentheses.

a Fetuses were injected with the solvent used for the glucagon and insulin solutions.

P $<<0.05$

c $P<0.02\}$ when compared to control, Student unpaired t test.

d $P<0.01$

NS - not significant.

\section{Hepatic Distribution Ratio of Nonmetabolizable Amino Acids}

In untreated animals given ${ }^{14} \mathrm{C}$-AIB and ${ }^{14} \mathrm{C}$-cycloleucine, a marked intensification of in vivo hepatic accumulation occurred from the fetus to the 4-h old newborn (Table 4A). The distribution ratios in the adult were of the same order of magnitude as in the fetus, and thus were lower than in the $4 \mathrm{~h}$ newborn.

Exogenous hormones administered to full-term fetuses in utero caused the following changes (Table 4B): glucagon increased hepatic accumulation of both amino acids to values equivalent to those observed in untreated $4 \mathrm{~h}$ newborn. By contrast, injection of insulin had no effect on the distribution ratios of either ${ }^{14} \mathrm{C}$-AIB or ${ }^{14} \mathrm{C}$-cycloleucine.

In accord with these in vivo results were those obtained using liver slices of fetal rats injected $4 \mathrm{~h}$ previously with glucagon. The distribution ratios calculated as in vivo, but comparing intracellular fluid with incubation medium radio-activity, were as follows: for the solvent-injected controls $(\mathrm{n}=10), 3.40$ \pm 0.24 , and for the glucagon-injected donors $(\mathrm{n}=$ 
Table 3. Plasma amino acids $(\mu \mathrm{M})$ in newborn rats $4 \mathrm{~h}$ after injection with various glucoregulatory hormones, or glucose

\begin{tabular}{lccccc}
\hline n & Control $^{\mathrm{a}}$ & Glucagon & Insulin & Glucose & Cortisol \\
\hline & $(5)$ & $(4)$ & $(5)$ & $(5)$ & $(5)$ \\
Taurine & $133 \pm 14$ & $251 \pm 23^{\mathrm{d}}$ & $102 \pm 16$ & $152 \pm 16$ & $495 \pm 62^{\mathrm{d}}$ \\
Aspartic acid & $37 \pm 2$ & $44 \pm 3$ & $26 \pm 5$ & $38 \pm 2$ & $96 \pm 6^{\mathrm{d}}$ \\
Threonine & $91 \pm 8$ & $116 \pm 5$ & $64 \pm 14$ & $49 \pm 2^{\mathrm{d}}$ & $231 \pm 6^{\mathrm{d}}$ \\
Serine & $151 \pm 14$ & $140 \pm 4$ & $99 \pm 22$ & $49 \pm 11^{\mathrm{d}}$ & $362 \pm 31^{\mathrm{d}}$ \\
Asparagine & $79 \pm 6$ & $76 \pm 6$ & $45 \pm 3^{\mathrm{d}}$ & - & $185 \pm 6^{\mathrm{d}}$ \\
Glutamine & $407 \pm 46$ & $282 \pm 43$ & $256 \pm 62$ & $244 \pm 16^{\mathrm{d}}$ & $1189 \pm 31^{\mathrm{d}}$ \\
Glutamic acid & $153 \pm 13$ & $142 \pm 10$ & $92 \pm 17^{\mathrm{b}}$ & $135 \pm 6$ & $369 \pm 21^{\mathrm{d}}$ \\
Proline & $105 \pm 24$ & - & - & - & $273 \pm 13^{\mathrm{d}}$ \\
Citrulline & $31 \pm 5$ & $21 \pm 1$ & $12 \pm 3^{\mathrm{b}}$ & $16 \pm 4^{\mathrm{b}}$ & $49 \pm 7$ \\
Glycine & $249 \pm 24$ & $246 \pm 11$ & $187 \pm 37$ & $132 \pm 10^{\mathrm{d}}$ & $665 \pm 30^{\mathrm{d}}$ \\
Alanine & $219 \pm 18$ & $184 \pm 11$ & $89 \pm 24^{\mathrm{d}}$ & $104 \pm 7^{\mathrm{d}}$ & $1094 \pm 43^{\mathrm{d}}$ \\
Valine & $110 \pm 13$ & $102 \pm 5$ & $72 \pm 19$ & $53 \pm 3^{\mathrm{d}}$ & $184 \pm 18^{\mathrm{d}}$ \\
Half cystine & - & $62 \pm 9$ & $41 \pm 6$ & - & - \\
Methionine & - & $42 \pm 6$ & $34 \pm 6$ & - & - \\
Isoleucine & $43 \pm 4$ & $45 \pm 4$ & $33 \pm 7$ & & $62 \pm 5^{\mathrm{c}}$ \\
Leucine & $78 \pm 8$ & $71 \pm 3$ & $52 \pm 10$ & $49 \pm 3^{\mathrm{d}}$ & $117 \pm 10$ \\
Tyrosine & $182 \pm 24$ & $86 \pm 3^{\mathrm{c}}$ & $161 \pm 27$ & $114 \pm 3^{\mathrm{b}}$ & $247 \pm 22$ \\
Phenylalanine & $76 \pm 8$ & $79 \pm 5$ & $54 \pm 7$ & $57 \pm 3^{\mathrm{d}}$ & $110 \pm 1^{\mathrm{d}}$ \\
Ornithine & $22 \pm 2$ & $19 \pm 2$ & $13 \pm 4$ & $9 \pm 2^{\mathrm{d}}$ & $88 \pm 8^{\mathrm{d}}$ \\
Lysine & $220 \pm 36$ & $296 \pm 14$ & $113 \pm 14^{\mathrm{b}}$ & $26 \pm 2^{\mathrm{d}}$ & $604 \pm 35^{\mathrm{d}}$ \\
Histidine & $71 \pm 4$ & $73 \pm 5$ & $58 \pm 7$ & $36 \pm 3^{\mathrm{d}}$ & $159 \pm 19^{\mathrm{d}}$ \\
Arginine & $56 \pm 8$ & $20 \pm 3^{\mathrm{d}}$ & $27 \pm 7^{\mathrm{b}}$ & - & $159 \pm 30^{\mathrm{c}}$ \\
\hline
\end{tabular}

Means \pm standard error of the mean of the number of observations shown in parentheses.

${ }^{a}$ Injected with physiologic saline.

b $P<0.05$

c $\mathrm{P}<0.02\}$ when compared to control, by Student's unpaired t test.

d $P<0.01$

$10), 5.30 \pm 0.28$. The difference was significant $(\mathrm{P}<$ $0.01)$.

\section{Conversion of Labelled Amino Acids into Glucose}

Experiments in Vivo. Injection of glucagon into fetal rats in utero $4 \mathrm{~h}$ before delivery by Caesarean section markedly enhanced the ability of 1-h old newborn rats to convert 2 of the 3 substrates tested into glucose (Table 5). The conversion of lactate was enhanced seven fold and that of alanine twofold, but glutamine conversion was unchanged despite the apparent increase in percent conversion.

Injection of insulin or glucose into newborn rats at delivery inhibited the ability of 4-h old newborn rats to convert the 4 substrates tested when compared with controls (Table 6). The inhibition with insulin was, for lactate, 2.5-fold; alanine, 9-fold; serine, 5-fold; and glutamine, 3-fold, and it was greater with glucoserespectively 3.6 -fold for lactate, 13 -fold for alanine and 16-fold for serine. By contrast, injection of glucagon into newborn rats at delivery increased the ability of 4-h old newborn rats to convert lactate to glucose and, although its effects upon amino acid conversion were significant, they were of smaller magnitude.

Cortisol injection into newborn rats at delivery increased the ability of 4-h old newborn rats to convert lactate, alanine and serine into glucose (Table 5). The conversion of lactate was enhanced 1.5 -fold, that of alanine 5.7-fold and that of serine 3 -fold.

Experiments in Vitro. The in vitro incorporation of labelled substrate into glucose was also enhanced 2 to 3 -fold in liver slices of glucagon-injected fetal rats (Table 7).

\section{Discussion}

The present study is an attempt to clarify the relative roles of the hormones and of substrate supply in the transformation of the liver to a glucose producing organ immediately after birth in the rat. The working hypothesis is that insulin plays the predominant intrauterine role in growth promotion by producing a markedly anabolic "set" for the fetus. The continuous 
Table 4. Hepatic uptake of model amino acids in full-term fetal, 4-h old newborn and adult rats

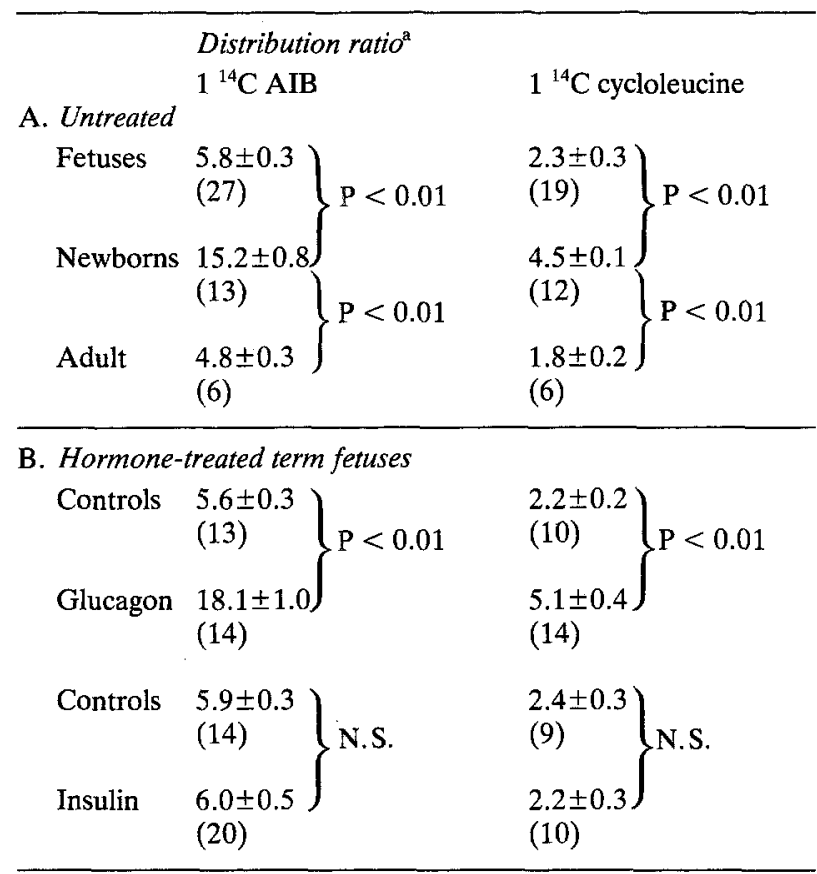

a Calculated as defined in the text.

Mean \pm SEM of the number of observations shown in parentheses. $P$ values were calculated using Student's unpaired $t$ test. NS $=$ not significant.

fuel provision as glucose from the maternal circulation renders it unnecessary for the liver to produce glucose from glycogenolysis or gluconeogenesis. At birth a marked change occurs such that it is incumbent upon the newborn to activate rapidly mechanisms for hepatic glucose production. It seems probable that these are due to the demonstrated fall in insulin and dramatic rise in glucagon in the immediate neonatal period [1, 13], though the limiting role of substrate and energy supply has been demonstrated in the newborn rat fasted $16 \mathrm{~h}$ [10].

The effects of insulin, glucagon and cortisol on glycemia in both fetal and newborn rats were significant and in the predicted directions. It is noteworthy, however, that the fetus and newborn showed no significant increase in glucagon levels with the insulin-induced hypoglycemia, nor suppression due to the exogenous-glucose induced increase in glycemia. This is consistent with the relatively poor response of the fetal and neonatal A-cell to glycemic alterations [4, 21]. By contrast, cortisol stimulated glucagon secretion in newborn rats even in presence of hyperglycemia. This effect has also been observed in adult man $[27,28]$. That the neonatal B-cell is capable of an insulin response to glucose [21] is supported by the impressive levels seen in the glucose-treated newborn
Table 5. Estimated in vivo rates of gluconeogenesis in 1-h old newborn rats. Glucagon $(10 \mu \mathrm{g})$ or solvent in utero was administered $4 \mathrm{~h}$ before birth. Labelled substrates were injected intraperitoneally at $0.5 \mathrm{~h}$

\begin{tabular}{|c|c|c|c|}
\hline Substrate & Controls $^{\mathrm{a}}$ & Glucagon & $\mathbf{P}<$ \\
\hline \multicolumn{4}{|l|}{ 1. Lactate } \\
\hline $\begin{array}{l}\text { Blood concentration } \\
(\mathrm{mM})\end{array}$ & $\begin{array}{l}5.43 \pm 0.17 \\
(5)\end{array}$ & $\begin{array}{l}4.96 \pm 0.40 \\
(5)\end{array}$ & N.S. \\
\hline $\begin{array}{l}\text { Pool size } \\
\text { ( } \mu \text { moles })\end{array}$ & $\begin{array}{l}18.1 \pm 0.6 \\
(5)\end{array}$ & $\begin{array}{l}16.4 \pm 1.30 \\
(5)\end{array}$ & N.S. \\
\hline $\begin{array}{l}\text { Conversion to glucose } \\
-\% \text { at } 30 \mathrm{~min}\end{array}$ & $\begin{array}{l}0.70 \pm 0.08 \\
(10)\end{array}$ & $\begin{array}{l}5.05 \pm 1.00 \\
(10)\end{array}$ & 0.01 \\
\hline $\begin{array}{l}-\mu \text { moles } / \mathrm{hr} / 100 \mathrm{~g} \\
\text { body wt. }\end{array}$ & $2.28 \pm 0.36$ & $14.91 \pm 4.03$ & \\
\hline \multicolumn{4}{|l|}{ 2. Alanine } \\
\hline $\begin{array}{l}\text { Plasma concentration } \\
(\mu \mathrm{M})\end{array}$ & $\begin{array}{l}520 \pm 20 \\
(5)\end{array}$ & $\begin{array}{l}380 \pm 50 \\
(5)\end{array}$ & 0.05 \\
\hline $\begin{array}{l}\text { Pool size } \\
\text { ( } \mu \text { moles) }\end{array}$ & $\begin{array}{l}1.72 \pm 0.07 \\
(5)\end{array}$ & $\begin{array}{l}1.26 \pm 0.17 \\
(5)\end{array}$ & 0.05 \\
\hline $\begin{array}{l}\text { Conversion to glucose } \\
-\% \text { at } 30 \mathrm{~min}\end{array}$ & $\begin{array}{l}1.04 \pm 0.15 \\
(10)\end{array}$ & $\begin{array}{l}2.70 \pm 0.45 \\
(10)\end{array}$ & 0.01 \\
\hline $\begin{array}{l}-\mu \text { moles } / \mathrm{hr} / 100 \mathrm{~g} \\
\text { body wt. }\end{array}$ & $0.30 \pm 0.04$ & $0.68 \pm 0.12$ & \\
\hline \multicolumn{4}{|l|}{ 3. Glutamine } \\
\hline $\begin{array}{l}\text { Plasma concentration } \\
(\mu \mathrm{M})\end{array}$ & $\begin{array}{l}563 \pm 54 \\
(5)\end{array}$ & $\begin{array}{l}370 \pm 50 \\
(5)\end{array}$ & 0.05 \\
\hline $\begin{array}{l}\text { Pool size } \\
\text { ( } \mu \text { moles) }\end{array}$ & $\begin{array}{l}1.85 \pm 0.18 \\
(5)\end{array}$ & $\begin{array}{l}1.23 \pm 0.16 \\
(5)\end{array}$ & 0.05 \\
\hline $\begin{array}{l}\text { Conversion to glucose } \\
-\% \text { at } 30 \mathrm{~min}\end{array}$ & $\begin{array}{l}1.30 \pm 0.07 \\
(10)\end{array}$ & $\begin{array}{l}2.40 \pm 0.24 \\
(10)\end{array}$ & 0.05 \\
\hline $\begin{array}{l}-\mu \text { moles } / \mathrm{hr} / 100 \mathrm{~g} \\
\text { body wt. }\end{array}$ & $0.43 \pm 0.06$ & $0.50 \pm 0.10$ & N.S. \\
\hline
\end{tabular}

a Fetuses received an equal volume of the solvent used to prepare the glucagon solution.

rats. Similarly, the insulin rise in glucagon-treated fetuses and newborn and cortisol-treated newborn is partly attributable to hyperglycemia. However, certain of the levels of hormone achieved after injection were clearly in the pharmacological range (e.g. insulin in the fetuses, cortisol in the newborns) and any conclusion relative to their role in physiological conditions must be guarded.

\section{Plasma Amino Acids}

Injection of glucagon into the full-term rat fetus produced a fall in most of the amino acids, whereas the same dose was without effect in the newborn rat. It is likely that in the newborn rat, the high endogenous plasma glucagon levels $[1,4]$ already exerted a maxi- 
Table 6. Estimated in vivo rates of gluconeogenesis in $4.5 \mathrm{~h}$ old newborn rats. Insulin ( $40 \mathrm{mU})$, glucagon ( $10 \mu \mathrm{g})$, cortisol $(0.1 \mathrm{mg})$, or solvent was administered at delivery. Glucose $(10 \mathrm{mg})$ was administered at delivery and at $2 \mathrm{~h}$ after birth. Labelled substrates were injected intraperitoneally at $4 \mathrm{~h}$

\begin{tabular}{|c|c|c|c|c|c|}
\hline Substrate & Controls $^{\mathbf{a}}$ & Insulin & Glucagon & Cortisol & Glucose \\
\hline \multicolumn{6}{|l|}{ 1. Lactate } \\
\hline $\begin{array}{l}\text { Blood concentration } \\
(\mathrm{mM})\end{array}$ & $\begin{array}{l}3.08 \pm 0.15 \\
(6)\end{array}$ & $\begin{array}{l}2.81 \pm 0.09 \\
(6)\end{array}$ & $\begin{array}{l}2.78 \pm 0.08 \\
(6)\end{array}$ & $\begin{array}{l}4.59 \pm 0.50^{d} \\
(5)\end{array}$ & $\begin{array}{l}3.48 \pm 0.50 \\
(5)\end{array}$ \\
\hline $\begin{array}{l}\text { Pool size } \\
\text { ( } \mu \text { moles) }\end{array}$ & $\begin{array}{l}13.5 \pm 0.6 \\
(6)\end{array}$ & $\begin{array}{l}12.4 \pm 0.4 \\
(6)\end{array}$ & $\begin{array}{l}10.9 \pm 0.3 \\
(6)\end{array}$ & $\begin{array}{l}18.4 \pm 0.8 \\
(5)\end{array}$ & $\begin{array}{l}13.2 \pm 0.5 \\
(6)\end{array}$ \\
\hline $\begin{array}{l}\text { Conversion to glucose } \\
-\% \text { at } 30 \mathrm{~min}\end{array}$ & $\begin{array}{l}6.9 \pm 0.6 \\
(10)\end{array}$ & $\begin{array}{l}2.8 \pm 0.6^{c} \\
(10)\end{array}$ & $\begin{array}{l}13.4 \pm 2.3^{b} \\
(6)\end{array}$ & $\begin{array}{l}7.6 \pm 0.8 \\
(5)\end{array}$ & $\begin{array}{l}1.9 \pm 0.1^{\mathrm{d}} \\
(5)\end{array}$ \\
\hline $\begin{array}{l}-\mu \text { moles } / \mathrm{hr} / 100 \mathrm{~g} \\
\text { body wt. }\end{array}$ & $18.6 \pm 0.8$ & $6.2 \pm 1.3$ & $28.1 \pm 6.5$ & $28.0 \pm 3.7$ & $5.1 \pm 0.4$ \\
\hline \multicolumn{6}{|l|}{ 2. Alanine } \\
\hline $\begin{array}{l}\text { Plasma concentration } \\
(\mu \mathrm{M})\end{array}$ & $\begin{array}{l}219 \pm 17 \\
(5)\end{array}$ & $\begin{array}{l}89 \pm 24^{d} \\
(5)\end{array}$ & $\begin{array}{l}183 \pm 11 \\
(4)\end{array}$ & $\begin{array}{l}1094 \pm 43^{d} \\
(5)\end{array}$ & $\begin{array}{l}104 \pm 7^{d} \\
(5)\end{array}$ \\
\hline $\begin{array}{l}\text { Pool size } \\
\text { ( } \mu \text { moles })\end{array}$ & $\begin{array}{l}0.72 \pm 0.06 \\
(5)\end{array}$ & $\begin{array}{l}0.29 \pm 0.08 \\
(5)\end{array}$ & $\begin{array}{l}0.60 \pm 0.03 \\
(4)\end{array}$ & $\begin{array}{l}4.37 \pm 0.17 \\
(5)\end{array}$ & $\begin{array}{l}0.41 \pm 0.03 \\
(5)\end{array}$ \\
\hline $\begin{array}{l}\text { Conversion to glucose } \\
-\% \text { at } 30 \mathrm{~min}\end{array}$ & $\begin{array}{l}5.0 \pm 0.3 \\
(10)\end{array}$ & $\begin{array}{l}1.3 \pm 0.3^{d} \\
(10)\end{array}$ & $\begin{array}{l}6.9 \pm 0.6^{b} \\
(6)\end{array}$ & $\begin{array}{l}4.3 \pm 0.4 \\
(5)\end{array}$ & $\begin{array}{l}0.6 \pm 0.1^{\mathrm{d}} \\
(5)\end{array}$ \\
\hline$-\mu$ moles $/ \mathrm{hr} / 100 \mathrm{~g}$ & $0.648 \pm 0.072$ & $0.072 \pm 0.020$ & $0.745 \pm 0.070$ & $3.7 \pm 0.4$ & $0.05 \pm 0.01$ \\
\hline \multicolumn{6}{|l|}{ 3. Serine } \\
\hline $\begin{array}{l}\text { Plasma concentration } \\
(\mu \mathrm{M})\end{array}$ & $\begin{array}{l}151 \pm 14 \\
(5)\end{array}$ & $\begin{array}{l}99 \pm 22 \\
(5)\end{array}$ & $\begin{array}{l}140 \pm 4 \\
(4)\end{array}$ & $\begin{array}{l}362 \pm 31^{d} \\
(5)\end{array}$ & $\begin{array}{l}49 \pm 11^{d} \\
(5)\end{array}$ \\
\hline $\begin{array}{l}\text { Pool size } \\
\text { ( } \mu \text { moles) }\end{array}$ & $\begin{array}{l}0.50 \pm 0.05 \\
(5)\end{array}$ & $\begin{array}{l}0.33 \pm 0.07 \\
(5)\end{array}$ & $\begin{array}{l}0.46 \pm 0.02 \\
(4)\end{array}$ & $\begin{array}{l}1.45 \pm 0.12 \\
(5)\end{array}$ & $\begin{array}{l}0.19 \pm 0.04 \\
(5)\end{array}$ \\
\hline $\begin{array}{l}\text { Conversion to glucose } \\
-\% \text { at } 30 \mathrm{~min}\end{array}$ & $\begin{array}{l}7.1 \pm 0.7 \\
(10)\end{array}$ & $\begin{array}{l}2.4 \pm 0.6^{\mathrm{C}} \\
(10)\end{array}$ & $\begin{array}{l}10.0 \pm 1.7^{b} \\
(6)\end{array}$ & $\begin{array}{l}6.6 \pm 0.4 \\
(6)\end{array}$ & $1.0 \pm 0.2^{\mathrm{d}}$ \\
\hline $\begin{array}{l}-\mu \text { moles } / \mathrm{hr} / 100 \mathrm{~g} \\
\text { body wt. }\end{array}$ & $0.640 \pm 0.09$ & $0.14 \pm 0.04$ & $0.830 \pm 0.013$ & $1.9 \pm 0.3$ & $0.04 \pm 0.01$ \\
\hline \multicolumn{6}{|l|}{ 4. Glutamine } \\
\hline $\begin{array}{l}\text { Plasma concentration } \\
(\mu \mathrm{M})\end{array}$ & $\begin{array}{l}407 \pm 46 \\
(5)\end{array}$ & $\begin{array}{l}256 \pm 62 \\
(5)\end{array}$ & $\begin{array}{l}282 \pm 43 \\
(4)\end{array}$ & - & - \\
\hline $\begin{array}{l}\text { Pool size } \\
(\mu \text { moles })\end{array}$ & $\begin{array}{l}1.34 \pm 0.15 \\
(5)\end{array}$ & $\begin{array}{l}0.84 \pm 0.20 \\
(5)\end{array}$ & $\begin{array}{l}0.93 \pm 0.14 \\
(4)\end{array}$ & - & - \\
\hline $\begin{array}{l}\text { Conversion to glucose } \\
-\% \text { at } 30 \mathrm{~min}\end{array}$ & $\begin{array}{l}2.4 \pm 0.2 \\
(10)\end{array}$ & $\begin{array}{l}1.4 \pm 0.1^{\mathrm{c}} \\
(10)\end{array}$ & $\begin{array}{l}5.6 \pm 0.7^{c} \\
(6)\end{array}$ & - & - \\
\hline $\begin{array}{l}-\mu \text { moles } / \mathrm{hr} / 100 \mathrm{~g} \\
\text { body wt. }\end{array}$ & $0.58 \pm 0.08$ & $0.22 \pm 0.06$ & $0.94 \pm 0.18$ & - & - \\
\hline
\end{tabular}

Means \pm SEM of the number of observations in parentheses.

a Controls received an equal volume of the solvent used to prepare the hormone solutions.

b $\mathbf{P}<0.05$

c $P<0.02\}$ when compared to control, Student's unpaired $t$ test.

d $\mathrm{P}<0.01$

mal effect upon plasma amino acids, and that further addition of glucagon was, therefore, without effect. This may explain the apparent inability of the human newborn to extract alanine from the plasma after glucagon stimulation on the first day of life [29], since in the human newborn [30-32] as in the newborn rat, the increase of plasma glucagon observed immediately after birth could mediate the spontaneous decrease in plasma gluconeogenic amino acids, including alanine [29].

The present data on the hypoaminoacidemic effect of glucagon in the fetus are in agreement with 
Table 7. Gluconeogenesis in vitro by liver slices from full-term fetal rats injected with glucagon $(10 \mu \mathrm{g})$ or solvent $4 \mathrm{~h}$ before delivery

\begin{tabular}{lllll}
\hline Substrate & & $\mathrm{n}$ & $\mu$ moles/hr/g wet liver slices & $\mathrm{P}<$ \\
\hline Lactate & Controls & $(10)$ & $1.25 \pm 0.06$ & \\
& Clucagon (10) & $3.85 \pm 0.42$ & 0.01 \\
Alanine & Controls (10) & $0.99 \pm 0.03$ & \\
& Glucagon (10) & $2.52 \pm 0.19$ & 0.01 \\
Serine & Controls (10) & $1.87 \pm 0.15$ & \\
& Glucagon (10) & $3.31 \pm 0.24$ & 0.01 \\
\hline
\end{tabular}

previous observations in adult human $[33,34,35]$ and rabbit [36]. Since glucagon at the dose used stimulated insulin secretion by the fetal pancreas, the hypoaminoacidemia produced by glucagon must in part have been insulin-mediated. However, the present findings demonstrate that the decrease in plasma amino acids, elicited by glucagon, was very different from that produced by large doses of exogenous insulin. In the rat fetus, glucagon decreased the level of all the gluconeogenic amino acids which are extracted by the isolated perfused rat liver under the influence of glucagon [37]. By contrast, insulin decreased only alanine and glutamine in this group and the fall of plasma alanine was of smaller magnitude than that produced by glucagon.

Hence, it seems reasonable to infer that the reduction in the level of gluconeogenic amino acids produced by glucagon in the rat fetus is largely a reflection of enhanced hepatic uptake.

The fall in valine and leucine after glucagon injection into the rat fetus was probably mediated by the release of insulin.

Exogenous injection of insulin into the rat fetus induced a fall in the level of all three branched-chain amino acids. Since these amino acids are not taken up by the liver [37] and are mainly utilized by muscle [38] and since glucagon infusion in the perfused rat hindquarter [39] has no effect on the release of amino acids by muscle, it may be inferred that the effect observed was mediated by insulin. This may be via a stimulation of aminoacid uptake and protein synthesis in fetal muscles [40, 41].

Exogenous injection of insulin in newborn rats appeared much less potent than glucose-induced endogenous insulin release in decreasing plasma amino acid levels. This may be due simply to the higher plasma insulin levels observed after injection of glucose, than after exogenous insulin. It could relate as well to a lesser sensitivity of fetal tissues to the species of exogenous insulin, namely a mixture of beef and pork. The suppression of peripheral release of amino acids and/or the stimulation of protein synthesis is perhaps also more sensitive to insulin at normal or elevated blood glucose level (term rat fetus injected with insulin or newborn rat injected with glucose) than at low blood glucose (newborn rat injected with insulin). The effects of insulin or glucose were independent of variations in plasma glucagon levels, and hence not mediated by this hormone.

Corticosteroid administration to the newborn rats produced a dramatic increase in plasma amino acid levels which is probably the result of an increased peripheral protein breakdown, since the proteolytic activity of corticosteroids is well documented in adult tissues [38]. The hyperglycemia observed after cortisol administration in newborn rats was clearly the result of an increased gluconeogenesis in response to substrate availability and stimulation of glucagon secretion.

\section{Hepatic Accumulation of Amino Acids}

The present data conforms with the original findings of Christensen and Clifford [42] showing an intensification of hepatic uptake of cycloleucine in newborn guinea-pig and with our recent observations in newborn rats [10]. Several lines of evidence suggest that the increase in hepatic accumulation of nonmetabolizable model amino acids in newborn rats is glucagon-mediated. First, the time course of the rise in plasma glucagon after birth is appropriate to influence the increase in accumulation of AIB and cycloleucine in the newborn rat liver. Second, exogenous glucagon injected into full-term fetal rats markedly increased the hepatic uptake of AIB and cycloleucine. Third, an increase in hepatic cyclic AMP occurs at birth in the rat $[6,43,44,45]$, an expected consequence of the plasma glucagon increase, and exogenous cyclic AMP increases hepatic uptake of AIB in newborn rats [45] and in human fetal liver explants in culture [46]. Taken together, these results are consistent with an effect of glucagon on hepatic amino acid transport, mediated by cyclic AMP in fetal and newborn rats.

Despite the glucagon-mediated insulin secretion by the fetal pancreas the increase in hepatic uptake of model amino acids was not a consequence of insulin, because exogenous insulin did not increase the hepatic accumulation of AIB or cycloleucine. From these data, it can be inferred that glucagon directly stimulates the hepatic transport of natural amino acids insofar as the control of the transport of AIB and cycloleucine is equivalent to that of the natural amino acids.

\section{Gluconeogenesis in Vivo}

The administration of glucagon to the fetus markedly enhanced the conversion of isotopic lactate and alanine to glucose when the latter were given $0.5 \mathrm{~h}$ 
after birth. A similar finding was reported for lactate when glucagon was injected immediately after birth in the rat [47]. The increased gluconeogenesis in both is likely to be due to the increased activity of liver phosphoenol-pyruvate carboxykinase (PEPCK) [13] and amino acid uptake. The conversion of glutamine into glucose was not stimulated by glucagon. However, glutamine is a poorer glucogenic substrate for the liver, and is preferentially used for renal gluconeogenesis [48]. Glucagon in the newborn rat at delivery increased the ability of $4 \mathrm{~h}$ old newborn rats to convert lactate into glucose, but the stimulatory effect with alanine, serine and glutamine was much less marked. Again, this could well be due to the utilization of amino acids for gluconeogenesis being maximally stimulated by endogenous glucagon.

Insulin or glucose injection into newborn rat at delivery markedly inhibited the capacity of the newborn rat to convert lactate and amino acids to glucose. The decrease was much more pronounced for amino acids than for lactate since insulin or glucose decreased both the plasma levels of amino acids and their conversion to glucose. As there appears to be no specific transport system for lactate in the liver, the inhibition of gluconeogenesis might be related to the decreased activity of liver PEPCK induced by insulin [13]. since in vivo insulin appeared to be capable of stimulating amino acids disposal in the direction of muscle for uptake and protein synthesis, the greater decrease in gluconeogenesis from amino acids induced by insulin or glucose may be related to decreased availability of substrate in addition to the lower activity of hepatic PEPCK. Cortisol injection into newborn rats at delivery markedly stimulated gluconeogenesis from lactate and amino acids. The increased gluconeogenesis in response to cortisol is likely to be due to increased peripheral lactate and amino acid production and to increased conversion of these substrates to glucose in the liver. This latter could result from the increased glucagon secretion in response to cortisol.

\section{Gluconeogenesis in Vitro}

Injection of glucagon into full-term rat fetuses $4 \mathrm{~h}$ before obtaining liver slices, and incubation with saturating levels of lactate or amino acids, markedly enhanced the conversion of these substrates into glucose. Similar results have been obtained previously with pyruvate as substrate [12]. These results corroborate the in vivo findings reported. In the same experimental conditions, glucagon has been shown to increase liver PEPCK activity 5-fold [13] and amino acid uptake $2-3$ fold.

There is evidence for the pattern of changes observed in the rat being representative of similar adaptations occurring in other species, though the total absence of fetal gluconeogenesis may be confined to the rodent. Thus, disorders of glucoregulation in the neonatal period may in part be explained by inadequate or inappropriate endocrine pancreatic responses at birth. If elevated insulin levels prevail in the full-term fetus, and persist after birth, suppression of the normal stimulation of endogenous glucose production would be predicted. Further, if an inadequate rise in glucagon secretion occurred at birth, with or without hyperinsulinaemia, again hypoglycaemia could occur. These have been proposed as operative mechanisms in the neonatal hypoglycaemia often seen in infants of diabetic mothers [30-31]. In addition to abnormalities in control of secretion of insulin and glucagon in the neonate, many disorders could be postulated which relate to the innate ability of the liver to respond to normal hormone levels, as well as to the adequacy of gluconeogenic substrate provision.

Acknowledgements. We are indebted to Dr. A. Kervran for the insulin assays presented in this article and to Dr. J. Jouve (Novo Industry) for the generous gift of Zinc-glucagon used in these experiments. The authors express their gratitude for the assiduous technical assistance of Mr. Chou-Nan Wei and Mrs. J. Boillot. Supported in part by grants from the Medical Research Council of Canada (MA-4782), The Dorothy Frances Graham Foundation (Toronto), and the Banting Research Foundation (Toronto), the Délégation Générale à la Recherche Scientifique et Technique (Contract 71.7.3250 and 74.70020).

\section{References}

1. Girard, J.R., Cuendet, G.S., Marliss, E.B., Kervran, A., Rieutort, M., Assan, R.: Fuels, hormones and liver metabolism at term and during the early postnatal period in the rat. J. clin. Invest. 52, 3190-322 (1973)

2. Haymond, M., Karl, I., Pagliara, A., Kipnis, D.: Glucose homeostasis in the newborn rat: Role of gluconeogenic substrates and ketones. J, clin. Invest. 51, (Abstr.), 43a (1972)

3. Wapnir, R. A., Tildon, J.T., Cornblath, M.: Metabolic differences in offspring of rats fed high-fat and control diets. Amer. J. Physiol. 224, 596-599 (1973)

4. Girard, J., Bal, D., Assan, R.: Glucagon secretion during the early postnatal period in the rat. Horm. Metab. Res. 4, 168-170 (1972)

5. Blazquez, E., Sugase, T., Blazquez, M., Foa, P.P.: The ontogeny of metabolic regulation in the rat with special reference to the development of insular function. Acta diabet. lat. 9 (Suppl. 1), 13-35 (1972)

6. Blazquez, E., Sugase, T., Blazquez, M., Foa, P.P.: Neonatal changes in the concentration of rat liver cyclic AMP and of serum glucose, free fatty acids, insulin, pancreatic and total glucagon in man and in rat. J. Lab. clin. Med. 83, 957-967 (1974)

7. Malinowska, K.W., Hardy, R.N., Nathanielsz, P.W.: Plasma adrenocorticosteroid concentrations immediately after birth in the rat, rabbit and guinea-pig. Experientia 28, 1366-1367 (1972)

8. Yeung, D., Oliver, I.T.: Gluconeogenesis from amino acids in neonatal rat liver. Biochem. J. 103, 744-748 (1967) 
9. Vernon, R. G., Eaton, S.W., Walker, D. G.: Carbohydrate formation from various precursors in neonatal rat liver. Biochem. J. 110, 725-731 (1968)

10. Girard, J. R., Guillet, I., Marty, J., Marliss, E. B.: Plasma amino acid levels and development of hepatic gluconeogenesis in the newborn rat. Amer. J. Physiol. 229, 466-473 (1975)

11. Yeung, D., Oliver, I.T.: Factors affecting the premature induction of phosphopyruvate carboxylase in neonatal rat liver. Biochem. J. 108, 325-331 (1968)

12. Phillipidis, H., Ballard, F.J.: The development of gluconeogenesis in rat liver. Effects of glucagon and ether. Biochem. J. 120, 385-392 (1970)

13. Girard, J. R., Caquet, D., Bal, D., Guillet, I.: Control of rat liver phosphorylase, glucose-6-phosphatase and phosphoenol pyruvate carboxykinase by insulin and glucagon during the perinatal period. Enzymologia 15, 272-285 (1973)

14. Hanson, R. W., Fisher, L., Ballard, F. J., Reshef, L.: The regulation of phosphoenol pyruvate carboxykinase in fetal rat liver. Enzymologia 15, 97-110 (1973)

15. Ballard, F.J.: Gluconeogenesis and the regulation of blood glucose in the neonate. In: Diabetes (eds. R.R. Rodriguez, J. Vallance-Owen), pp. 592-600. Excerpta Medica Foundation Publishers (Amst.) 1971

16. Pearce, P.H., Buirchell, B.J., Weaver, P. K., Oliver, I. T.: The development of phosphopyruvate carboxylase and gluconeogenesis in neonatal rats. Biol. Neonat. (Basel) 24, 320-329 (1974)

17. Cahill, G.F., Jr., Aoki, T.T., Marliss, E. B.: Insulin and muscle protein. In: Handbook of physiology. The endocrine pancreas, pp. 563-577. Washington: American Physiological Society 1972

18. Marliss, E.B., Aoki, T.T., Cahill, G.F., Jr.: Glucagon and amino acid metabolism. In: Glucagon (eds. P. J. Lefebvre, R. H. Unger), pp. 123-150. Oxford: Pergamon Press Ltd. 1972

19. Marliss, E.B., Aoki, T.T.: Hormonal control of amino acid metabolism in man. Relation to fasting and other physiologic and pathologic states. Acta diabet. lat. 9 (Suppl. 1), 189-225 (1972)

20. Goodner, C. J., Freinkel, N.: Carbohydrate metabolism in pregnancy. IV. Studies on the permeability of the rat placenta to I-131-insulin. Diabetes 10, 383-392 (1961)

21. Girard, J.R., Kervran, A., Soufflet, E., Assan, R.: Factors affecting the secretion of insulin and glucagon by the rat fetus. Diabetes 23, 310-317 (1974)

22. Exton, J.H., Park, C.R.: Control of gluconeogenesis in liver. I. General features of gluconeogenesis in the perfused livers of rats. J. biol. Chem. 242, 2622-2636 (1967)

23. Snell, K., Walker, D. G.: Glucose metabolism in the newborn rat. Temporal studies in vivo. Biochem. J. 132, 739-752 (1973)

24. Spector, W.S.: Handbook of biological data. (ed. W.S. Saunders), London: 1956

25. Olcott, R. J.: Confidence limits on the product of two uncertain numbers. Analyt. Chem. 45, 1737-1740 (1973)

26. Kadenburg, C.P.: A lithium buffer system for accelerated single column amino acid analysis in physiological fluids. Analyt. Biochem. 40, 35-42 (1971)

27. Marco, J., Calle, C., Roman, D., Diaz-Fierros, M., Villanueva, M., Valverde, I.: Hyperglucagonism induced by glucocorticoid treatment in man. New Engl. J. Med. 288, 128-133 (1973)

28. Wise, J. K., Hendler, R., Felig, P.: Influence of glucocorticoids on glucagon secretion and plasma amino acid concentration in man. J. clin. Invest. 52, 2774-2782 (1973)

29. Reisner, S.H., Aranda, J.V., Colle, E., Papageorgiou, A., Schiff, D., Scriver, C. R., Stern, L.: The effect of i.v. glucagon on plasma amino acids in the newborn. Pediat. Res. 7, 184-191 (1973)

30. Luyckx, A.S., Massi-Benedetti, F., Falorni, A., Lefebvre, P. J.: Presence of pancreatic glucagon in the portal plasma of human neonates. Differences in the insulin and glucagon responses to glucose between normal infants and infants from diabetic mothers. Diabetologia 8, 296-300 (1972)

31. Bloom, S.R., Johnston, D.I.: Failure of glucagon release in infants of diabetic mothers. Brit. med. J. 1972 IV, 453-454

32. Sperling, M. A., De la Mater, P. V., Phelps, D., Fiser, R. H., Oh, W., Fisher, D.A.: Spontaneous and amino acid stimulated glucagon secretion in the immediate postnatal period. Relation to glucose and insulin. J. clin. Invest. 53, 1159-1166 (1974)

33. Marliss, E. B., Aoki, T.T., Unger, R. H., Soeldner, J.S., Cahill, G.F., Jr.: Glucagon levels and metabolic effects in fasting man. J. clin. Invest. 49, 2256-2270 (1970)

34. Felig, P., Brown, W. V., Levine, R. A., Klatskin, G.: Glucose homeostasis in viral hepatitis. New Engl. J. Med. 283, 1436-1440 (1970)

35. Landau, R.L., Lugibihl, K.: Effect of glucagon on concentration of several free amino acids in plasma. Metabolism 18, 265-269 (1969)

36. Bromer, W.W., Chance, R.E.: Zinc-glucagon depression of blood amino acids in rabbits. Diabetes 18, 748-757 (1969)

37. Mallette, L. E., Exton, J.H., Park, C.R.: Effects of glucagon on amino acid transport and utilization in the perfused rat liver. $J$. biol. Chem. 244, 5724-5728 (1969)

38. Young, V.R.: The role of skeletal and cardiac muscle in the regulation of protein metabolism. In: Mammalian protein metabolism. Vol. 4 (H.N. Munro), pp. 585-670. New York: Academic Press 1970

39. Ruderman, N. B., Berger, M.: The formation of glutamine and alanine in skeletal muscle. Amer. J. Physiol. 249, 5500-5506 (1974)

40. Clark, C.M., Jr.: The stimulation by insulin of amino acid uptake and protein synthesis in the isolated fetal rat heart. Biol. Neonat. (Basel) 19, 379-388 (1971)

41. Fricke, R., Clark, C.M., Jr.: Augmentation of glucose and amino acid uptake by insulin in the developing rat diaphragm. Amer. J. Physiol. 224, 117-121 (1973)

42. Christensen, H.N., Clifford, J.B.: Early postnatal intensification of hepatic accumulation of amino acids. J. biol. Chem. 238, 1743-1745 (1963)

43. Novak, E., Drummond, G.I., Skala, J., Hahn, P.: Developmental changes in cyclic AMP, protein kinase, phosphorylase kinase and phosphorylase in liver, heart and skeletal muscle of the rat. Arch. Biochem. Biophys. 150, 511-518 (1972)

44. Christoffersen, T., Morland, J., Osnes, J. B., Oye, I.: Development of cyclic AMP metabolism in rat liver. A correlative study of tissue levels of cyclic AMP, accumulation of cyclic AMP in slices, adenylate cyclase activity and cyclic nucleotide phosphodiesterase activity. Biochim. biophys. Acta (Amst.) 313, 338-349 (1973)

45. Butcher, F.R., Potter, V.R.: Control of adenosine $3^{\prime} 5^{\prime}$ monophosphate-adenyl cyclase system in the liver of developing rats. Cancer Res. 32, 2141 (1972)

46. Schwartz, A.: Hormonal regulation of amino acid accumulation in human fetal liver explants. Effects of dibutyryl cyclic AMP, glucagon and insulin. Biochim. biophys. Acta (Amst.) 322, 276-289 (1974)

47. Snell, K., Walker, D.G.: Glucose metabolism in the newborn rat. Hormonal effects in vivo. Biochem. J. 134, 899-960 (1973)

48. Bowman, R.H.: Gluconeogenesis in the isolated perfused rat kidney. J. biol. Chem. 245, 1604-1612 (1970)

Received: December 22, 1975, and in revised form: April 29, 1976

Dr. J.R. Girard

Laboratoire de Physiologie du Développement

du Collège de France

Université Pierre et Marie Curie

9, quai Saint-Bernard

F-75230 Paris, Cedex 05

France 